\title{
Basic science (April 2006)
}

1. Amlal H, Faroqui $S$, Balasubramaniam $A$, Sheriff $S$. Estrogen up-regulates neuropeptide YY1 receptor expression in a human breast cancer cell line. Cancer Res 2006; 66: 3706-3714.

2. Aneja R, Lopus M, Zhou J, Vangapandu SN, Ghaleb A, Yao J, Nettles JH, Zhou BF, Gupta M, Panda D, Chandra R, Joshi HC. Rational design of the microtubule-targeting anti-breast cancer drug EM015. Cancer Res 2006; 66: 3782-3791.

3. Arendt LM, Rose-Hellekant TA, Sandgren EP, Schuler LA. Prolactin potentiates transforming growth factor alpha induction of mammary neoplasia in transgenic mice. Am J Pathol 2006; 168: 1365-1374.

4. Bramley M, Clarke RB, Howell A, Evans DGR, Armer T, Baildam AD, Anderson E. Effects of oestrogens and anti-oestrogens on normal breast tissue from women bearing BRCA1 and BRCA2 mutations. $\mathrm{Br} J$ Cancer 2006; 94: 1021-1028.

5. Burkhardt M, Mayordomo E, Winzer KJ, Fritzsche F, Gansukh T, Pahl S, Weichert W, Denkert C, Guski H, Dietel M, Kristiansen G. Cytoplasmic overexpression of ALCAM is prognostic of disease progression in breast cancer. J Clin Pathol 2006; 59: 403-409.

6. Callagy GM, Pharoah PD, Pinder SE, Hsu FD, Nielsen TO, Ragaz J, Ellis IO, Huntsman D, Caldas $\mathrm{C}$. $\mathrm{Bcl}-2$ is a prognostic marker in breast cancer independently of the Nottingham Prognostic Index. Clin Cancer Res 2006; 12: 2468-2475.

7. Chakraborty G, Rangaswami H, Jain S, Kundu GC. Hypoxia regulates cross-talk between Syk and Lck leading to breast cancer progression and angiogenesis. I Biol Chem 2006; 281: 11322-11331.

8. Charafe-Jauffret E, Ginestier C, Monville F, Finetti P, Adelaide J, Cervera N, Fekairi S, Xerri L, Jacquemier J, Birnbaum D, Bertucci F. Gene expression profiling of breast cell lines identifies potential new basal markers. Oncogene 2006; 25: 2273-2284.

First published online 19/07/06 BCO/565/2006/JW
9. Christensen LA, Finch RA, Booker AJ, Vasquez KM. Targeting oncogenes to improve breast cancer chemotherapy. Cancer Res 2006; 66: 4089-4094.

10. Cohen I, Pappo O, Elkin M, San T, Bar-Shavit R, Hazan R, Peretz T, Vlodavsky I, Abramovitch R. Heparanase promotes growth, angiogenesis and survival of primary breast tumors. Int $J$ Cancer 2006; 118: 1609-1617.

11. Creighton CJ, Hilger AM, Murthy S, Rae JM, Chinnaiyan AM, El-Ashry D. Activation of mitogenactivated protein kinase in estrogen receptor alpha-positive breast cancer cells in vitro induces an in vivo molecular phenotype of estrogen receptor alpha-negative human breast tumors. Cancer Res 2006; 66: 3903-3911.

12. Ding L, Erdmann C, Chinnaiyan AM, Merajver SD, Kleer CG. Identification of EZH2 as a molecular marker for a precancerous state in morphologically normal breast tissues. Cancer Res 2006; 66: 4095-4099.

13. Eliassen AH, Missmer SA, Tworoger SS, Hankinson SE. Endogenous steroid hormone concentrations and risk of breast cancer: does the association vary by a woman's predicted breast cancer risk? J Clin Oncol 2006; 24: 1823-1830.

14. Fernandez SV, Russo IH, Russo J. Estradiol and its metabolites 4-hydroxyestradiol and 2hydroxyestradiol induce mutations in human breast epithelial cells. Int J Cancer 2006; 118: 1862-1868.

15. Fisher JL, Thomas-Mudge RJ, Elliott J, Hards DK, Sims NA, Slavin J, Martin TJ, Gillespie MT. Osteoprotegerin overexpression by breast cancer cells enhances orthotopic and osseous tumor growth and contrasts with that delivered therapeutically. Cancer Res 2006; 66: 3620-3628.

16. Foekens JA, Atkins D, Zhang Y, Sweep F, Harbeck N, Paradiso A, Cufer T, Sieuwerts AM, Talantov D, Span PN, Tjan-Heijnen VCG, Zito AF, Specht K, Hoefler H, Golouh R, Schittulli F, Schmitt M, Beex L, Klijn IGM, Wang YX. Multicenter validation of a gene expressionbased prognostic signature in lymph nodenegative primary breast cancer. $J$ Clin Oncol 2006; 24: 1665-1671. 
17. Ginger MR, Shore AN, Contreras A, Rijnkels M, Miller J, Gonzalez-Rimbau MF, Rosen JM. A noncoding RNA is a potential marker of cell fate during mammary gland development. Proc Nat Acad Sci USA 2006; 103: 5781-5786.

18. Gururaj AE, Singh RR, Rayala SK, Holm C, den Hollander $P$, Zhang $H$, Balasenthil $S$, Talukder AH, Landberg G, Kumar R. MTA1, a transcriptional activator of breast cancer amplified sequence 3. Proc Nat Acad Sci USA 2006; 103: 6670-6675.

19. Han HJ, Heo JS, Lee YJ. Estradiol-17 beta stimulates proliferation of mouse embryonic stem cells: involvement of MAPKs and CDKs as well as protooncogenes. American J Physiol-Cell Physiol 2006; 290: C1067-C1075.

20. He B, Mirza M, Weber GF. An osteopontin splice variant induces anchorage independence in human breast cancer cells. Oncogene 2006; 25: 2192-2202.

21. Hirsch DS, Shen Y, Wu WJ. Growth and motility inhibition of breast cancer cells by epidermal growth factor receptor degradation is correlated with inactivation of Cdc42. Cancer Res 2006; 66: 3523-3530.

22. Holland JD, Kochetkova M, Akekawatchai C, Dottore M, Lopez A, McColl SR. Differential functional activation of chemokine receptor CXCR4 is mediated by G proteins in breast cancer cells. Cancer Res 2006; 66: 4117-4124.

23. Huh JI, Calvo A, Charles R, Green JE. Distinct tumor stage-specific inhibitory effects of 2-methoxyestradiol in a breast cancer mouse model associated with Id-1 expression. Cancer Res 2006; 66: 3495-3503.

24. Innes HE, Liu D, Barraclough R, Davies MPA, O'Neill PA, Platt-Higgins A, Rudland SD, Sibson DR, Rudland PS. Significance of the metastasisinducing protein AGR2 for outcome in hormonally treated breast cancer patients. $\mathrm{Br} \mathrm{J}$ Cancer 2006; 94: 1057-1065.

25. Irahara N, Miyoshi $\mathrm{Y}$, Taguchi T, Tamaki $\mathrm{Y}$, Noguchi S. Quantitative analysis of aromatase mRNA expression derived from various promoters (I.4, I.3, PII and I.7) and its association with expression of TNF-alpha, IL-6 and COX-2 mRNAs in human breast cancer. Int $J$ Cancer 2006; 118: 1915-1921.

26. Jackson JG, Pereira-Smith OM. Primary and compensatory roles for RB family members at cell cycle gene promoters that are deacetylated and downregulated in doxorubicin-induced senescence of breast cancer cells. Mol Cell Biol 2006; 26: 2501-2510.

27. Kanczuga-Koda L, Sulkowski S, Lenczewski A, Koda M, Wincewicz A, Baltaziak M, Sulkowska M.
Increased expression of connexins 26 and 43 in lymph node metastases of breast cancer. J Clin Pathol 2006; 59: 429-433.

28. Kim JY, Zhang XW, Rieger-Christ KM, Summerhayes IC, Wazer DE, Paulson KE, Yee AS. Suppression of Wnt signaling by the green tea compound (-)-epigallocatechin 3-gallate (EGCG) in invasive breast cancer cells - requirement of the transcriptional repressor HBP1. J Biol Chem 2006; 281: 10865-10875.

29. Kusano AS, Trichopoulos D, Terry KL, Chen WY, Willett WC, Michels KB. A prospective study of breast size and premenopausal breast cancer incidence. Int J Cancer 2006; 118: 2031-2034.

30. Masala G, Ambrogetti D, Assedi M, Giorgi D, Del Turco MR, Palli D. Dietary and lifestyle determinants of mammographic breast density. A longitudinal study in a Mediterranean population. Int $J$ Cancer 2006; 118: 1782-1789.

31. Maskarinec G, Pagano I, Lurie G, Kolonel LN. A longitudinal investigation of mammographic density: the multiethnic cohort. Cancer Epidem Biomar Prev 2006; 15: 732-739.

32. Miller WR, White S, Dixon JM, Murray J, Renshaw L, Anderson TJ. Proliferation, steroid receptors and clinical/pathological response in breast cancer treated with letrozole. Br J Cancer 2006; 94: 1051-1056.

33. Moreira PI, Custodio J, Moreno A, Oliveira CR, Santos MS. Tamoxifen and estradiol interact with the flavin mononucleotide site of complex I leading to mitochondrial failure. $J$ Biol Chem 2006; 281: 10143-10152.

34. Mukhina S, Liu DX, Guo K, Raccurt M, BorgesBendris S, Mertani HC, Lobie PE. Autocrine growth hormone prevents lactogenic differentiation of mouse mammary epithelial cells. Endocrinology 2006; 147: 1819-1829.

35. Nagaraja GM, Othman M, Fox BP, Alsaber R, Pellegrino CM, Zeng $Y$, Khanna R, Tamburini $P$, Swaroop A, Kandpal RP. Gene expression signatures and biomarkers of noninvasive and invasive breast cancer cells: comprehensive profiles by representational difference analysis, microarrays and proteomics. Oncogene 2006; 25: 2328-2338.

36. Nakopoulou L, Mylona E, Papadaki I, Kavantzas N, Giannopoulou I, Markaki S, Keramopoulos A. Study of phospho-beta-catenin subcellular distribution in invasive breast carcinomas in relation to their phenotype and the clinical outcome. Modern Pathol 2006; 19: 556-563.

37. Namba R, Young LJ, Abbey CK, Kim L, Damonte P, Borowsky AD, Qi JY, Tepper CG, MacLeod CL, Cardiff RD, Gregg JP. Rapamycin inhibits growth of premalignant and malignant 
mammary lesions in a mouse model of ductal carcinoma in situ. Clin Cancer Res 2006; 12: 2613-2621.

38. Oh DS, Troester MA, Usary L, Hu ZY, He XP, Fan C, Wu JY, Carey LA, Perou CM. Estrogenregulated genes predict survival in hormone receptor-positive breast cancers. J Clin Oncol 2006; 24: 1656-1664.

39. Paulus P, Stanley ER, Schafer R, Abraham D, Aharinejad S. Colony-stimulating factor-1 antibody reverses chemoresistance in human MCF-7 breast cancer xenografts. Cancer Res 2006; 66: 4349-4356.

40. Peng M, Litman R, Jin Z, Fong G, Cantor SB. $\mathrm{BACH} 1$ is a DNA repair protein supporting BRCA1 damage response. Oncogene 2006; 25: 2245-2253.

41. Pooley KA, Healey CS, Smith PL, Pharoah PDP, Thompson D, Tee L, West J, Jordan C, Easton DF, Ponder BAJ, Dunning AM. Association of the progesterone receptor gene with breast cancer risk: A single-nucleotide polymorphism tagging approach. Cancer Epidem Biomar Prev 2006; 15: 675-682.

42. Pukrop T, Klemm F, Hagemann T, Gradl D, Schulz M, Siemes S, Trumper L, Binder C. Wnt 5 a signaling is critical for macrophage-induced invasion of breast cancer cell lines. Proc Nat Acad Sci USA 2006; 103: 5454-5459.

43 Quan XJ, Laes JF, Stieber D, Riviere M, Russo J, Wedekind D, Coppieters W, Farnir F, Georges M, Szpirer J, Szpirer C. Genetic identification of distinct loci controlling mammary tumor multiplicity, latency, and aggressiveness in the rat. Mamm Genome 2006; 17: 310-321.

44. Smolen GA, Muir B, Mohapatra G, Barmettler A, Kim WJ, Rivera MN, Haserlat SM, Okimoto RA, Kwak E, Dahiya S, Garber JE, Bell DW, Sgroi DC, Chin L, Deng CX, Haber DA. Frequent met oncogene amplification in a Brca1/Trp53 mouse model of mammary tumorigenesis. Cancer Res 2006; 66: 3452-3455.

45. Stone J, Dite GS, Gunasekara A, English DR, McCredie MRE, Giles GG, Cawson JN, Hegele RA, Chiarelli AM, Yaffe MJ, Boyd NF, Hopper JL. The heritability of mammographically dense and nondense breast tissue. Cancer Epidem Biomar Prev 2006; 15: 612-617.

46. Sukocheva O, Wadham C, Holmes A, Albanese N, Verrier E, Feng F, Bernal A, Derian CK, Ullich A, Vadas MA, Xia P. Estrogen transactivates
EGFR via the sphingosine 1-phosphate receptor Edg-3: the role of sphingosine kinase-1. J Cell Biol 2006; 173: 301-310.

47. Tan M, Lan KH, Yao J, Lu CH, Sun MH, Neal CL, Lu J, Yu DH. Selective inhibition of ErbB2overexpressing breast cancer in vivo by a novel TAT-based ErbB2-targeting signal transducers and activators of transcription 3-blocking peptide. Cancer Res 2006; 66: 3764-3772.

48. Tanaka H, Shirkoohi R, Nakagawa K, Qiao HJ, Fujita H, Okada F, Hamada J, Kuzumaki S, Takimoto M, Kuzumaki N. siRNA gelsolin knockdown induces epithelial-mesenchymal transition with a cadherin switch in human mammary epithelial cells. Int $J$ Cancer 2006; 118: 1680-1691.

49. Thuerigen O, Schneeweiss A, Toedt G, Warnat $P$, Halm M, Kramer H, Brors B, Rudlowski C, Benner A, Schuetz F, Tews B, Eils R, Sinn HP. Gene expression signature predicting pathologic complete response with gemcitabine, epirubicin, and docetaxel in primary breast cancer. J Clin Oncol 2006; 24: 1839-1845.

50. Tong D, Czerwenka K, Heinze G, Ryffel M, Schuster E, Witt A, Leodolter S, Zeillinger R. Expression of KLF5 is a prognostic factor for disease-free survival and overall survival in patients with breast cancer. Clin Cancer Res 2006; 12: 2442-2448.

51. Trock BJ, Hilakivi-Clarke L and Clarke R. Metaanalysis of soy intake and breast cancer risk. J Nat/ Cancer I 2006; 98: 459-471.

52. Vaclavicek A, Hemminki K, Bartram CR, Wagner K, Wappenschmidt B, Meindl A, Schmutzler RK, Klaes $R$, Untch $M$, Burwinkel $B$, Forsti $A$. Association of prolactin and its receptor gene regions with familial breast cancer. J Clin Endocrinol Metabol 2006; 91: 1513-1519.

53. Yao J, Weremowicz S, Feng B, Gentleman RC, Marks JR, Gelman R, Brennan C, Polyak K. Combined cDNA array comparative genomic hybridization and serial analysis of gene expression analysis of breast tumor progression. Cancer Res 2006; 66: 4065-4078.

Prepared by

R. Sutherland, J. Scorer Cancer Research Program Garvan Institute of Medical Research Darlinghurst, NSW, Australia 